\title{
En knute på akvarieeiers hånd
}
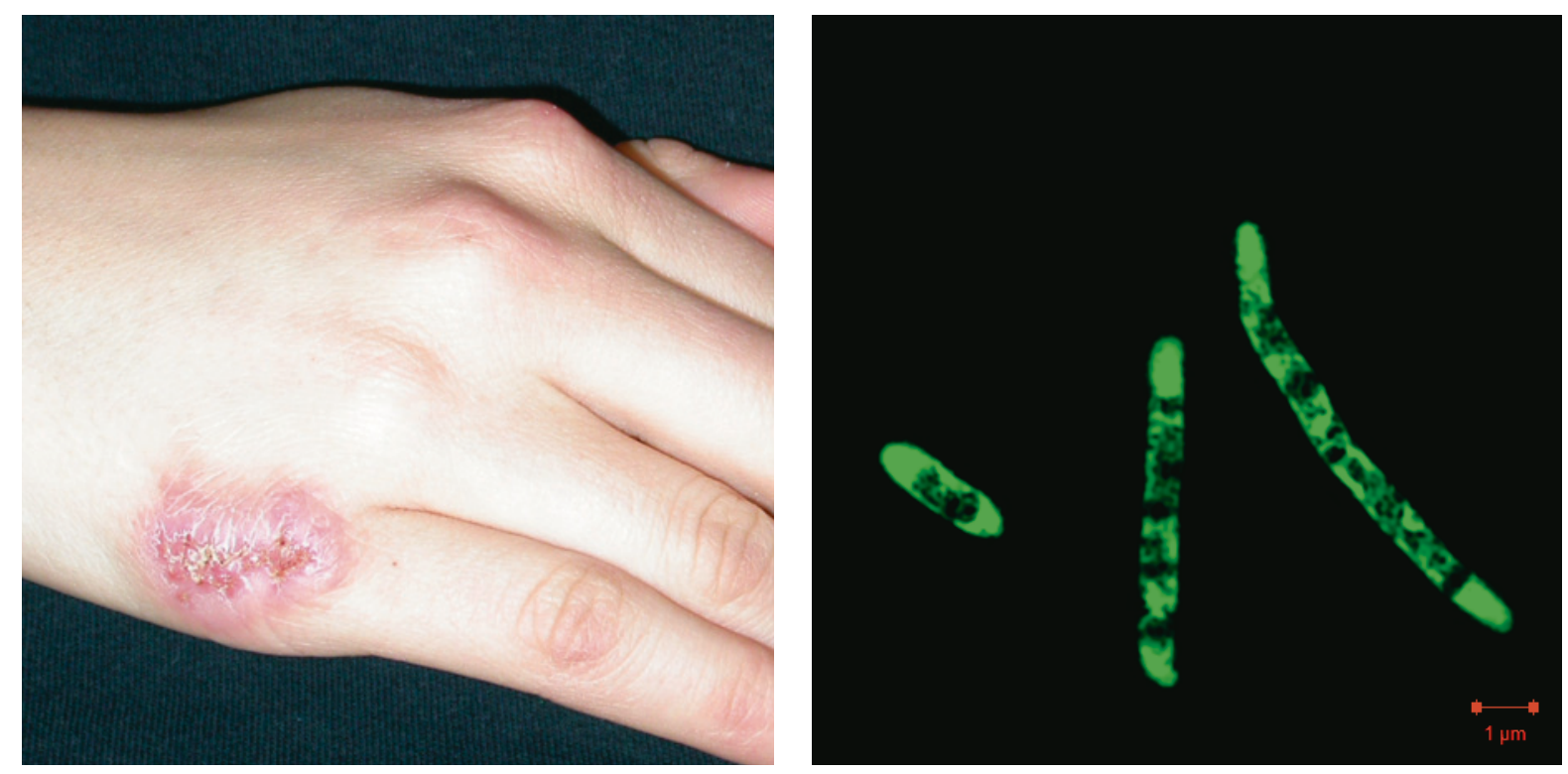

En jente i tenårene utviklet $\mathrm{i}$ løpet av to år en hudlesjon på høyre håndrygg. Hun søkte flere allmennleger og gjennomgikk flere antibiotikakurer - uten effekt. Hun var ikke BCG-vaksinert. Det var positiv mantouxtest, men røntgenundersøkelse av thorax og hånd viste ingen forandringer som kunne gi mistanke om tuberkulose.

Ved klinisk undersøkelse hadde pasienten en velavgrenset oval, $25 \times 20 \mathrm{~mm}$ stor, erytematøs, infiltrert og noe hyperkeratotisk nodulus (venstre bilde). Medialt på samme overarm hadde hun restforandringer etter en tilsvarende lesjon som hadde gått spontant tilbake noen år tidligere. Somatisk undersøkelse for øvrig var upåfallende. Histologisk undersøkelse av hudbiopsi viste uspesifikke inflammatoriske forandringer uten tegn til mykose, orf eller granulomer.

Ved fornyet anamnese fremkom det at pasienten hadde hatt akvarium hjemme i over fem år, og at hun regelmessig matet fiskene, rengjorde akvariet og skiftet vann uten å bruke hansker. Dette ga mistanke om infeksjon med Mycobacterium marinum, en atypisk mykobakterie som kan infisere akvariefisk. Ny biopsi, denne gangen fra kanten av lesjonen, viste hud med granulomatøs betennelse med langerhanske kjempeceller. Dyrking av biopsi på $7 \mathrm{H} 10$-medium ved $32{ }^{\circ} \mathrm{C}$ viste etter flere uker oppvekst av bakterier. Direkte mikroskopi med auraminfarging viste syrefaste stavbakterier (høyre bilde), som ble identifisert som $M$. marinum ved 16S rRNAgensekvensering (1). Polymerasekjedereaksjonstest for $M$. tuberculosis var negativ.

Diagnosen M. marinum-infeksjon stilles ofte sent, bl.a. fordi den er lite kjent blant leger. Avgjørende er å stille spørsmålet om pasienten er akvarieeier eller har med fisk eller vannreservoarer å gjøre - da kan man ta de rette prøver som vil sikre diagnosen. M. marinum, som er nær beslektet med M. tuberculosis, kan påvises i akvarier og svømmebassenger og infiserer mennesket gjennom små traumer i huden (2). Den er vanligvis sensitiv overfor flere typer antibiotika, bl.a. tetrasykliner, som foretrekkes fremfor antituberkuløse midler som rifampicin og etambutol. Spontan remisjon forekommer.

Pasienten har gitt samtykke til at artikkelen blir publisert.

\section{Panagiota Mantaka}

Seksjon for hudsykdommer

Oslo universitetssykehus

\section{Tone Tønjum}

Avdeling for mikrobiologi

Oslo universitetssykehus og

Universitetet i Oslo

\section{Petter Gjersvik}

petter.gjersvik@medisin.uio.no

Institutt for klinisk medisin

Universitetet i Oslo
Panagiota Mantaka (f. 1968) er spesialist i hudog veneriske sykdommer.

Forfatter har fylt ut ICMJE-skjemaet og oppgir ingen interessekonflikter.

Tone Tønjum (f. 1958) er overlege og professor i medisinsk mikrobiologi.

Forfatter har fylt ut ICMJE-skjemaet og oppgir ingen interessekonflikter.

Petter Gjersvik (f. 1952) er førsteamanuensis i dermatologi.

Forfatter har fylt ut ICMJE-skjemaet og oppgir ingen interessekonflikter.

\section{Litteratur}

1. Tønjum T, Welty DB, Jantzen E et al. Differentiation of Mycobacterium ulcerans, M. marinum, and M. haemophilum: mapping of their relationships to M. tuberculosis by fatty acid profile analysis, DNADNA hybridization, and 16S rRNA gene sequence analysis. J Clin Microbiol 1998; 36: 918-25.

2. Bonamonte D, De Vito D, Vestita M et al. Aquarium-borne Mycobacterium marinum skin infection. Report of 15 cases and review of the literature. Eur J Dermatol 2013; 23: 510-6.

Mottatt 4.11. 2013, første revisjon innsendt 9.1. 2014, godkjent 17.1. 2014. En av forfatterne er redaktør i Tidsskriftet. Manuskriptet er derfor behandlet eksternt av en uavhengig redaktør. Michael Bretthauer. 